\title{
Beyond the Realm: The Loss of Culture as the Colonial Condition
}

\section{CHARLOTTE MACDONALD}

Three bullock drivers, alive in the archive of nineteenth-century New Zealand, open this excursion into the anxiety and iconoclasm of the Victorian world, a key context for culture-making in the colonial period. Noting Carolyn Steedman's injunction to historians to 'observe where you are' at the conclusion of her meditation on culture and history, it was these very solid figures who appeared on my research horizon as we were invited to think 'beyond representation'.

Working at Kurow Station in the Waitaki Valley in the winter of 1863, bullock driver R. Murray found his trousers had worn through. He went to his boss, station overseer William McCulloch, to get a new pair. McCulloch obliged. A claim for $25 \mathrm{~s}$ reimbursement for the trousers supplied by Dalgety Rattray was among the many pieces of paper McCulloch sent to join the fast mounting pile before Robert Chapman, registrar at the Dunedin Supreme Court. Kurow Station had, until March 1862, been the property of John McLean. Following his death one Sunday night, after falling from a chair in his living room in a drunken stupor and hitting his head on the floor, sustaining injuries from which he died, the property had fallen into the hands of the court as McLean died intestate (without leaving a will).

The story of the property, including a failed charge of wilful murder against John McLean's wife, Hannah, the adulterous goings-on of McCulloch's predecessor as overseer, David Gray; Gray's subsequent bankruptcy, and much more besides, rests in copious files in the Dunedin office of Archives New Zealand. While reading the file for quite different purposes, the tangible materials of nineteenth-century life insistently pressed on my attention: inventories of goods, careful measures of items - rice, flour, cornstarch, muslin, cordial and gin - kept in the homestead store, and, after McLean's death, behind a locked door to which the manager McCulloch had access but not the widow Hannah. Amidst the dense legal trail was a claim for $25 \mathrm{~s}$ reimbursement for a pair of trousers for Murray, the bullock driver. $^{2}$

A young William Rolleston, later provincial superintendent and national politician, is the second bullock driver. A product of an English vicarage, and of a Cambridge education (but one in which his second-class honours was a source of deep disappointment), Rolleston arrived in Lyttelton in 1858. 
He was 26 years old and eager to launch into a new life. ${ }^{3}$ In an enchanting passage in Samuel Butler's First Year in Canterbury Settlement, he appears as one of the four men Butler meets at Lake Coleridge Station in his first venture up-country. Living in a hut with 'no boarded floors, no chairs, nor similar luxuries', their existence he describes as 'a kind of mixture of that of a dog and that of an emperor, with a considerable predominance of the latter'. To his amazement, Butler discovers that the 'men are all gentlemen and sons of gentlemen', and under their simple bunks they have books. The titles include Tennyson's Idylls of the King and works by Ovid and Sophocles. Amidst the remote valleys, and the work of the sheep run, Rolleston, Butler noted, had time to study, and to exercise his Greek and Latin on his bullock team and, on occasional trips to town, on the sixth form at Christ's College where he served as examiner. ${ }^{4}$

The third bullock driver remains unknown by name. He was also living and working on a sheep run in the Canterbury foothills, but further south, a year or two later, at Samuel Butler's Mesopotamia run at the headwaters of the Rangitata. And it was this man who came to the fore when Dr Sinclair, former colonial secretary and keen botanist, accompanying Julius von Haast on an expedition in the area was tragically drowned. Butler was absent at the time. His companions searched the station, in vain, for a prayer book from which to read the burial service. In the end Haast found the bullock driver had a mass book, and took the service with that volume in hand. ${ }^{5}$

What do my bullock drivers tell us?

The work of reading and writing in each of these settings speaks to the variety of ways in which culture was formed: in mud and work, in the consumption of goods, in volatile intimacies, in the reach of legal process, in the crises of life and death and the rites by which they were marked, and in the hunger of well-trained minds for continued nourishment. Everywhere, words mattered. In colonial New Zealand, paper, books, carefully fashioned pictures, writing and reading were to be found in even the most incongruous places and circumstances. In the calloused hands of men engaged in the rough labour and crude surroundings of the back country, words held a currency. ${ }^{6}$ A pervading fear, evident in the archive of 'settler' correspondence from nineteenth-century New Zealand, that colonial life might be attended by a loss of culture found reassurance in evidence of reading, writing, an appreciating eye, educated tastes and habits. Such scenes underscore the distinctive character of colonial space. But observing these three bullock drivers, and their companions, in the early 1860s is to note a particular time as well as the specifics of place. It is to be in the midst of a Victorian world.

As the interdisciplinary project of 'Victorian Studies' has been overshadowed by approaches to cultural history which emphasize colonial 
conflict in national histories, or by the strong spatial approaches to 'new studies of empire' and sites of cultural formation, and by its competing notion of a 'British world', this is a context that has faded from view. 'Yet it has value in drawing attention to what might be unfashionably referred to as the characteristics of an age. The lengthy, familial reign of Victoria (1837-1901), a continuity that acquired its own solidity, was a political formation of significance in the making of colonial histories. Occupying the greater part of the span Hobsbawm divides into the Age of Revolution (1789-1848), the Age of Capital (1848-1875) and the Age of Empire (18751914), the Victorian world was alive with invention and uncertainty. ${ }^{8}$ In such circumstances anxiety and iconoclasm were rife. Doubt and faith were not confined to individual struggles with the soul, but burst open in a major crisis in the wake of Darwin's On the Origin of Species (1859). Fortunes, and with them social position, were there to be won, and lost. The interlinking of political demands with economic position was all the more evident following the conflagrations of 1848. In the pursuit of family and individual prospects, the shadowy presence of those whose threadbare respectability or prudential stricture had not saved them from falling below the level of penury was a reminder of the dire pall cast by widowhood, too large a family, or sickness.

In the discussion that follows I trace the uncertainty of the Victorian world through aspects of New Zealand colonial culture of the 1850s and early 1860s. Samuel Butler (1835-1902), author of the celebrated dystopia Erewhon (1872), and, for a time, youthful Canterbury pastoralist, provides one thread. The family correspondence of settler migrants, including Margaret Herring and Sarah Greenwood, provides a second. Both take us to the archive in which the novelty and often discordant nature of colonial life are strongly recorded. The culture of writing was stimulated by the sometimes alarming, sometimes exciting process of 'becoming colonial'. It existed alongside a lively production of pictures, including portraits, and a rapidly developing technology of image-making. Portraits, whether in ink and paint, daguerreotype, photographs or the cartes-de-visite of the 1860s, formed part of the Victorian world of connection and exchange. Both threads also suggest significant ways in which 'colonial' writing, published and unpublished, was part of a wider grappling with the perplexities of the age: Butler's struggle with Christianity and convention, the Herrings' struggle with distance and proprieties of social conduct, Sarah Greenwood's struggle with the death of a child. In these predicaments, cultures of reading, writing, and the making and exchange of portraits proved vital to contemporaries. They remain essential as elements in the archive from which historical understandings are derived. 
What is suggested is the way in which the larger 'Victorian world' (and in particular the preoccupations of the mid-Victorian era) served to frame a colonial history. Local colonial histories took place within a larger Victorian realm, and were, in turn, part of shaping that wider frame. Here it is most obviously seen in the imaginative creation of Samuel Butler, but also in the less conspicuous, but perhaps no less influential flow, of family correspondence.

Twenty-five-year-old Samuel Butler arrived in New Zealand at the end of January 1860. Exalting in a safe landfall at the end of a four-month sea voyage, Butler and his shipmates - young men in their early twenties, with public school and Oxbridge educations behind them - spent their first evening ashore building a large bonfire. Onto it they threw their top hats and tailcoats. As the fire burned, they danced around the flames in jubilation. ${ }^{9}$ Shrugging off the trappings of an old life in order to embrace the new may have been an intoxicating occasion in more ways than one. But an apprehension that becoming colonial might come at the cost of a loss of culture was brought home to Butler a few days later. While staying at the Mitre Hotel in Lyttelton he overheard an exchange between guests staying in the neighbouring room through the flimsy partitions as he was preparing to go through to dinner. The conversation went as follows:

'Have you washed yet?'

'No'.

'Don't you mean to wash this year?'

'No'.

When these same guests turned up in the hotel dining room clean and respectably dressed he realized they were sheep farmers talking shop, not personal grooming. ${ }^{10}$

Butler relished New Zealand for the distance it set between himself and Langar Rectory, his difficult relationship with his father, and his escape from a future in the church. Refusing to be ordained cut deeply across family relations. His path from belief and orthodox adherence to unbelief and iconoclasm began the very first night he was on board the Roman Emperor, the ship on which he sailed from England in September 1859. While still at Gravesend, before the final anchors had been weighed, he went to sleep without saying evening prayers - a lack of observance he continued for the rest of his life. ${ }^{11}$ The beginning of the voyage marked a first step away from convention. Butler's four and a half years in New Zealand, 1860-64, were critical in his deepening commitment to unbelief. In that time he also undertook a series of explorations in the Canterbury high country, contributed articles to the Press, engaged in a searching study of Darwin's Origins and 
the New Testament, participated in Christchurch's social and musical circles, and doubled his capital by successfully developing a sheep run. The bullockdriving world of early 1860 s South Island pastoralism proved a fertile place to pursue the bounds of religion, science and livelihood. It was a place of cultural production that was as 'Victorian' as it was 'colonial'.

For all his singularity, Butler shared his contemporaries' reliance on correspondence to sustain his business, friendships and familial relations. In the early 1860 s the opportunities to send mail, together with the news of incoming post, provided one of the strongest, if still unevenly paced, rhythms within colonial communities. Letters comprised a valued part of the material world, both the paper, ink and time needed to write those sent, as well as those received, read and carefully stored. It is from that safekeeping that the historical entity of the archive was later built. ${ }^{12}$ The novelty of colonial conditions continued as a subject of curiosity in the correspondence of emigrant newcomers writing 'back' to those they had left. The inverted nature of life in the antipodes forms a recurring theme. January heat and June cold, Christmas celebrated in mid-summer amidst bright sun, the southern cross in the night sky, public buildings designed for stone but built in wood vividly impressed on new arrivals their position at the furthest point on the globe. At the same time, such observations served to remind their readers that the distance that now fell between them was not just one of geographical separation but also of predictable familiarities. Upside-down seasons might preface things out of order - or even emptied altogether - in other domains.

At the very least, incongruity was something people came to expect. Material conditions and outward appearances were often poor guides to cultural and social habits and contours. As Butler discovered on his early journey to Lake Coleridge, the mud floors and lack of furniture in which Rolleston and his companions were living were only one side of a life that also contained books and time for poetry. In the Hutt Valley around the same time, 23-year-old Margaret Herring was startled by the state of the table laid out by the wealthy and educated Bartons, the leading residents in the district where her husband was about to become the clergyman. On a visit to the Bartons, a genuine hospitality was extended and intelligent conversation offered. But the 'half style and half dilapidation' of arrangements meant the table was set with 'silver sugar basin and rusty iron salt spoons, silver table spoons and common brassy looking forks and [an] old tin tea pot'. ${ }^{13}$ The oddity was recorded in a letter Margaret wrote to her sister Nellie. Colonial circumstances did not dissolve anxieties about social position, wealth and education, and the means by which these were signified, but made them less predictable terrain to negotiate. In the still small but rapidly consolidating settlements of the early 1860 s these could prove teasing problems. ${ }^{14}$ 
Butler's correspondence, and Margaret Herring's letters to her sister Nellie and to a circle of friends, testify to the great work of ongoing connection that the archive of personal correspondence presents. The near-ubiquitous occupations of letter writing, and reading, in colonial New Zealand underscore the anxieties attendant on the displaced connectedness of an emigrant community. Distance and separation, a condition of migration, created a spur to communication. Exchanges conveyed news, affect, money, but were also maintained for the sake of connection, of staying 'in touch' as an end in itself. The continued arrival of letters was, at the very least, reassurance that the correspondent was still alive (or had been so fairly recently). Looking and seeing as well as reading and writing formed part of these lines of connection. The world of words, written and spoken, printed and handwritten, was supplemented by a world of images.

Amongst the profuse personal archive of correspondence and family papers are images and portraits - sketches, watercolours, oils and photographs. Having a portrait made was part of many better-off colonists' preparations as they embarked. Portraits were left behind and taken as reminders, representations to answer in the face of the separation distance imposed and against the broader shadow of mortality. As John Sullivan has recently noted, photographs "were made to be sent rather than kept . . . . Through photographs, immigrants told their families about their new lives, their friends, and their farms. In return, they received pictures of growing nieces and nephews, prospective in-laws, celebrities, and other links to the familiar world across the sea. ${ }^{15}$ Exchanging images as part of correspondence was common. They were highly-prized objects. Samuel Butler tracked his journeyings in a series of portraits. He had his photograph taken in London as part of his preparations for departure for New Zealand in $1859 .{ }^{16}$ In 1862 he had a further studio portrait made in Christchurch. ${ }^{17}$ Returning to England, he completed at least two self-portraits in 1866 and 1873. The oblique head-and-shoulders paintings convey a strength that belied Butler's pronounced self-consciousness about his short, dark and swarthy appearance. ${ }^{18}$ Later in his life, photography became the major vehicle for his artistic ambition. ${ }^{19}$

Geoffrey Batchen reminds us of the contingency and commerce involved in the production of image-making, and especially photography, over the course of the nineteenth century. Rather than emphasizing a history driven by technical invention, Batchen points to the development and innovation of photography as an industry. The businesses of Henry Fox-Talbot, Antoine Claudet and Richard Beard (the last a trademark as much as an artist) testify to the rapid growth and huge success of a new form of imagemaking and circulation from the $1850 \mathrm{~s}^{20}$ The commercial growth witnessed the emergence of new sets of labour expertise and relations, but also the 
presentation of photography within the framework of art. Going to get photographed, and the production of cartes-de-visite in the 1860s, brought a new repertoire of social behaviour and means of communicating into the Victorian world.

In the colonial context, portraits, whether in sketches or in the increasingly common form of photographs, could carry a special significance in bridging the ache of distance. At times when that was hard felt, and in the sharp pain of death and mourning, a visual as well as written connection was often sought out. Finding consolation and company in the presence of images was a common subject in personal correspondence from the 1850s. Portraits continued to live in the world of their owners. Margaret and John Herring spent their first Christmas in New Zealand in December 1861. Arriving two months before, they had spent some time in Nelson, but were in Wellington at the end of the year. The Herrings spent Christmas as guests of Bishop Charles and Caroline Abraham. Before attending morning service Margaret took time to write to her friends and family, telling them how they have spent this first special day in their new colonial surroundings: 'We have been spending half an hour in England with all the portraits round us, fancying them real flesh and blood and talking to them and kissing them as though they were. I hope this is not silly but they are so very precious we can't help being silly over them. I am wondering so much what you are going to do today . . . ${ }^{21}$ Letter writing was a way to spend time in the company of those at a distance, to imagine their presence and 'speak' on the page. Doing so in the presence of visual representations of those addressed added a similitude to the moment.

In the crises of life and death, anxieties not unique to the Victorian world but with their own specific histories of observance, the material world of letter exchange and the specific material forms of remembrance, in image or in other forms, were especially important. ${ }^{22}$ They were also prompts for particular forms of cultural production. In July 1854, Sarah Greenwood wrote from Nelson to her mother in Surrey, telling of her daughter's death. The letter is also a heartfelt plea for the return of a portrait Sarah had sent two years earlier, one of a set of family portraits Sarah had made and sent, representations of her growing family. Sarah and husband John Danforth Greenwood left England for Nelson in 1842 with eight children. Their remaining five were colonial-born. Sarah's letter of 23 July 1854 is a letter written to her mother on a Sunday morning as she sits beside the bed on which her 13-year-old daughter Agnes lies dead. Unlike most of Sarah's letters it is brief, and unmasked.

My dear Mother

Three weeks back, I finished a letter to Ann [Sarah Greenwood's sister], telling her of all our anxieties about our children, their suffering from 
the fever which may be called the complaint of this country; I am still writing at the same table by the same bed-side, but it has pleased God to take our dear, dear Agnes to Himself, and she is now lying in all the solemn stillness of death on the bed she has so long occupied in patient endurance, though not (I am thankful to say) in much suffering.

You know my dear Mother, that the idea of death has never been a frightful thought to me, either personally or for those near and dear to me when I felt persuaded of their acceptance and salvation by their God and Saviour; still, you who have experienced it can best understand the agony of tender regret and yearning love, when first all hope of a dear child's restoration is entirely crushed by death. Our dear Agnes died on Friday evening last, July 21st aged thirteen and a half, without the least struggle. Her breathing had been very hard all day, and the phlegm in the throat painfully oppressive; but we did not expect any immediate change, when I was startled by the entire stillness from the bed and found that she was indeed gone from us.

And now my dear Mother will you grant me a favour? namely to send me back by the first post convenient to Ellen my likeness of my dear child. My heart yearns to see it, and it will be a delightful task to me to copy it. You shall be sure to have it restored to you, I hope also to send one of Graham to accompany it. There is no need to wait for a vessel starting for New Zealand direct, merely put the letter in the Mitcham post and it will be forwarded by the Sydney Mail.

Pray do not be seduced to let Fanny [Sarah's sister] or any one else detain the little last portrait to make a copy of it, as it would cause a delay which I should much bewail, and it will travel perfectly well in a letter folded large. ${ }^{23}$

In time, Sarah Greenwood received the portrait back. Created in Nelson, it had travelled to England and back again. While the Greenwoods came through the 1854 fever crisis, and went on to leave a mark on the cultural life of the colony, they were never able to increase their capital in the way Butler did so effectively in his pastoral venture. Losing money in an early investment in a French cement works in the mid-1830s was one of the spurs to the Greenwoods' interest in the New Zealand Company scheme. When the flax-milling machinery they brought with them to Nelson also proved unprofitable, they were forced to rely on loans from family in England. The family's education, secure faith, hard work and settled position in Nelson made the Greenwoods 'successful' colonists by other measures. It was a pattern in stark contrast to Samuel Butler's adventurous, profitable but rather brief interlude as a bachelor sheep farmer. 
Samuel Butler's abrupt departure from New Zealand in June 1864 was later a matter of regret, especially the rupture it caused to several friendships. But his return to London enabled him to take up the vocation he most craved, that of art. He applied himself with great diligence as a student at two art schools, Cary's and later Heatherley's. But his writing also continued. In Erewhon, or Over the Range, published first anonymously in 1872, his experience in Canterbury formed the basis for a highly original and deeply cutting critique of contemporary life. In a landscape highly reminiscent of that he traversed when exploring the Rakaia and Rangitata headwaters in 1860, his fair-haired and blue-eyed narrator finds himself in a formidable and frightening place of roaring towers and plunging chasms. But having navigated through this place of dread, he emerges 'over the range' into a land of sunny harmony. The new world the narrator reaches does not turn out to be a place of personal transformation, or redemption, a common designation for colonial destinations in the Victorian imagination. Instead, the world 'over the range' is a place of startling novelty and inversion where the narrator is subjected to a gentle but concerted re-education. His major crime, the owning and wearing of a watch, leads to his arrest and imprisonment. In Erewhon machines have been banned.

In Butler's imaginary world beyond the realm, the celebration and progress of the machine has no place. A commentary on God's role in the design of the universe and on Darwin's theory of evolution, the denial of such objects of Victorian modernity was highly provocative. Equally contrary was the Erewhonian practice in which sickness was treated as a crime, and crime as a sickness. 'Offenders' were treated by officers known as 'straighteners', while the major institutions were Colleges of Unreason and Musical Banks (a searing satire of the contemporary church). Not surprisingly, the deepest offence to Butler's father and mother in the book was his invention of the 'Unborn', whose right it is to select their parents. In Erewhon parents had to endure their selection.

The narrator's attention is captivated by all of this, but also by the beautiful daughter of Mr Nosnibor, a leading citizen of this almost idyllic place, the young woman Arowhena. Through the eyes of the narrator, a young man but whose name we are not given (though subsequently identified as Higgs in the 1901 sequel Erewhon Revisited), we are led around the strange but beguiling world, introduced to its oddities and then faced with staying and accommodating to its attractive but offbeat ways - or not. The narrator's imprisonment is a captivity with silken bonds. He is taught the local language, treated rather as a patient than a criminal, and enjoys the company of the gaoler's daughter, whose name is Yram ('Mary' in reverse). Besides, his good behaviour and his fair hair mean he is likely to be treated favourably once he has served his sentence. Ultimately our narrator takes 
flight, literally, in a balloon with the lovely Arowhena at his side. In a postscript we see them marry and go happily off to a life together. There was no autobiographical base for this part of the plot.

The world of Erewhon and Butler was not a world without culture, though it was a world without religion, and even morality (of any recognisable form). Butler fed, and stirred, the Victorian imagination with his debunking fantasy. To celebrate outward appearance and make illness a matter of intolerance brought readers into individual as well as social perplexity. He was delightfully, playfully, shockingly unconventional. Erewhon was a moderate success when it first appeared, but has continued to gain in reputation. Butler's Erewhon took the inversions of colonial life to an extreme, extending and elaborating them to stab at the foundations of Victorian orthodoxy. The work presented one of the most iconoclastic visions of his age. While Erewhon was premised on two worlds, one known and near, and one distant 'over the range', it was anything but a simple rendering of old and new worlds, metropolitan and colonial places. Erewhon's godless world was not a depiction of colonial society, but drew some of its inspiration from its creator's colonial experience. The vigour, practicality, jumbled order of outward appearance and inner cultivation were features of his Canterbury life, which carried over into the imaginary domain.

To follow Butler into the dystopian world of Erewhon is to note the intermixing of imagination, experience and preoccupations of the midVictorian world. It is also to engage with the troubling questions of the age - the veracity and foundations of Christian belief, and of understandings of the nature of humanity, in the face of the radicalism of Darwin's theory of evolution; to challenge machines as engines of social as well as material progress; to prod at the bases and exercise of authority.

Beyond the realm, morally, materially and geographically, Butler is an extreme but very real figure in the reordering incongruity that colonial life brought to the Victorian world and to the Victorian imagination. The world Butler brought into being in Erewhon owed something to the muddy mix of bullock drivers and the exhilarating possibility he described with delight at Lake Coleridge in March 1860. At an extreme in the nineteenth-century spectrum, an anti-Victorian Victorian, Butler takes us to the ways and places in which culture was not lost, but made, in a Victorian as much as a colonial world. The world inhabited by Butler, the Herrings, the Greenwoods and many others for whom colonial New Zealand became their temporary or permanent home was one of particular anxieties and uncertainties. The novelty and incongruity of colonial life was both embraced for its freshness, but also startling and unnerving in its unorthodoxy. Writing and reading, along with the reassuring exchange of portraits (whether in the form of drawings, paintings or the later popular photographs) proved important means 
by which to accommodate displacement of a colonial world beyond the realm'. But these excursions into the mid-Victorian world of the 1850s and 1860s are also reminders of the distinctive preoccupations of the era. Recent emphasis on the space, mobility, webs and networks in which colonial and imperial histories were made have been extremely important in deepening understandings of the nineteenth century. Against this redrawn map of the colonial and imperial worlds it is useful to note the contingencies of time, the volatility of individual and social fortunes within the intellectual, religious and financial currents. Trousers wore out, flour was used up, bills were left outstanding, books were started and finished, services needed to be said - to mark the passing of life as well as the passing of Sunday - all of these things mark time.

In the paths along which cultural traffic passed in the mid-nineteenth century, iconoclasm and anxiety proved impulses and engines of cultural creation and communication. These were paths that not only tracked between metropolitan and colonial ports but which occupied a time whose fixations were marked by questioning, doubt, debunking and uncertainty. In the words produced under press of need, of commerce, of anger or love in family connections, in mourning and loss, meanings were made and remade in exchange. In the archive, they continue to be read in shaping historical understandings of the nineteenth century.

1 This article is a revised version of an address presented at the 'Beyond Representations: Cultural Histories in Colonial New Zealand' symposium, University of Otago, 17-19 November 2010. Steedman was paraphrasing W.H. Auden in 'Homage to Clio': Carolyn Steedman, 'Culture, Cultural Studies and the Historians', in Simon During, ed., The Cultural Studies Reader, London, 1993, p.56.

2 John McLean Estate, DAAC/9074/280 A1778; DAAC/D140/21, Archives New Zealand, Dunedin. The research project for which this archival trail was being pursued concerned the history of dower right ('the widow's third'): see Charlotte Macdonald, 'Land, Death and Dower in the Settler Empire: The Lost Cause of "the Widow's Third" in NineteenthCentury New Zealand', Victoria University of Wellington Law Review, 41, 3 (November 2010), pp.493-518.

3 W.J. Gardner, 'Rolleston, William', Dictionary of New Zealand Biography. Te Ara - the Encyclopedia of New Zealand, updated 1-Sep-10, http://www.TeAra.govt.nz/en /biographies/1r17/1

4 Samuel Butler, A First Year in Canterbury Settlement, London, 1863, A.C. Brassington and P.B. Maling, eds, Hamilton, 1964, pp.48-9.

5 Peter Raby, Samuel Butler: A Biography, London, 1991, p.78.

6 Lydia Wevers, Reading on the Farm: Victorian Fiction and the Colonial World, Wellington, 2010, provides a very rich exploration of reading on the North Island Wairarapa sheep run at Brancepeth for the later nineteenth century and early twentieth century.

7 Victorian Studies began publication with a first issue in 1957. The Victorian Studies Association and related scholarly meetings date from this same period. A Victorian 


\section{Journal of New Zealand Studies}

Studies course was taught as part of the MA degree at the University of Auckland in the late 1970s and 1980s (typically as a History and English joint enterprise, by Russell Stone and a colleague in the English Department).

8 E.J. Hobsbawm, The Age of Revolution, Europe 1789-1848, London, 1962; The Age of Capital, 1848-1875, London, 1975; The Age of Empire, 1875-1914, New York, 1987.

9 Raby, Samuel Butler, p.66. See also Roger Robinson, 'Butler, Samuel', Dictionary of New Zealand Biography. Te Ara - the Encyclopedia of New Zealand, updated 1-Sep-10, http://www.TeAra.govt.nz/en/biographies/1b55/1; Elinor Shaffer, 'Butler, Samuel (18351902)', Oxford Dictionary of National Biography, Oxford, 2004, online edn, May 2010, http://www.oxforddnb.com; Peter Maling, Samuel Butler at Mesopotamia, Wellington, 1960.

10 Raby, p.66.

11 Ibid., p.64.

12 See Steedman's reminder that the archive itself is an historical fact, not just a repository of historical facts: Steedman, p.56.

13 Margaret Herring to her sister Nellie, 1 Ocober 1861, in Frances Porter and Charlotte Macdonald, eds, 'My Hand Will Write What My Heart Dictates': The Unsettled Lives of Women in Nineteenth-Century New Zealand as Revealed to Sisters, Family and Friends, Auckland and Wellington, 1996, pp.169-70.

14 For further elaboration on this theme see Penny Russell, 'The Brash Colonial: Class and Comportment in Nineteenth-Century Australia', Transactions of the Royal Historical Society, 12 (2002), pp.431-53, and Savage or Civilised? Manners in Colonial Australia, Sydney, 2010.

15 John Sullivan, 'A Fijian in Bulls', Turnbull Library Record, 43 (2010/11), p.108.

16 Raby, p.59.

17 Reproduced as the frontispiece in Butler.

18 'Self-portrait', c.1873, Alexander Turnbull Library (ATL), Wellington; 'Self-portrait', 1866, Chapin Library, Williams College, Williamstown, Mass., USA.

19 Elinor Shaffer, Erewhons of the Eye: Samuel Butler as Painter, Photographer and Art Critic, London, 1988.

20 Geoffrey Batchen, 'Perplexity and Embarrassment: Photography as Work', research seminar, History, Victoria University of Wellington, 1 October 2010; Batchen, Burning with Desire: The Conception of Photography, Cambridge, 1997.

21 Margaret Herring to English friends, Christmas Day 1861, in Porter and Macdonald, p.97.

22 Patricia Jalland, Death in the Victorian Family, New York, 1996; Philip Cleaver, 'Dealing with Death: The Pakeha Treatment of Death', MA thesis, Victoria University of Wellington, 1996.

23 Sarah Greenwood to her mother, Mary Ann Field, 23 July 1854, MS-Papers-0098-11, ATL. See also Charlotte Macdonald, ed., Women Writing Home, 1700-1920: Female Correspondence across the British Empire, vol.5, New Zealand, London, 2006. 